\title{
Working Across Disciplines and Chipping Away at Silos with SLCE: An Interdisciplinary Approach to Educating Science and Engineering Students
}

\author{
Robert J. Swap \\ University of Virginia \\ Charlottesville, VA, USA \\ North West University \\ Potchefstroom, South Africa \\ rjswap@gmail.com
}

\author{
Kent Wayland \\ University of Virginia \\ Charlottesville, VA, USA \\ Kaw6r@virginia.edu
}

Abstract - A co-curricular approach to service-learning and community engagement (SLCE) designed to begin breaking through these institutional and personal silos that inhibit exchanges of knowledge between students, faculty and communities, is presented. This approach seeks to create a continuum of engagement and learning for students, faculty, and communities to redirect students and faculty away from the drive to solely produce a competitive product (or trophy) and toward an appreciation of the ongoing process of engagement. To construct this continuum, we draw on the idea of an intellectual apprenticeship. The students in this model serve as the apprentices, while the faculty, along with community partners and other colleagues, act as mentors in a guild of "artisans" dedicated to putting useful knowledge into action. We present the principles of engagement that underlay the entire process (respect, reciprocity and relationship), the stages of the apprenticeship, evidence that supports its effectiveness and challenges to the approach. The goal of the paper is to share the approach with the larger community so that others may borrow what they find useful and add what they believe to be missing to ultimately improve experiential education about SLCE for engineers and scientists.

Index Terms - curricular models for service-learning and community engagement, experiential learning, intellectual apprenticeship

\section{INTRODUCTION}

As noted by the Accreditation Board for Engineering and Technology, by employers, and by students, the world is ever more interconnected, and the question for higher education is how it should grapple with this complexity. One major response has been to take an economistic view and hold that the purpose of education is to prepare students for jobs in the global economy. According to this view, higher education should provide students with important skills to compete in the global marketplace. Critics have objected to this narrowing of the collegiate mission. In 2004, Vartan Gregorian, former president of Brown University and president of the Carnegie Corporation of New York, argued that "a major failure of our higher-education system is that it has largely come to serve as a job-readiness program.", The purpose of higher education had become, in his view, to train students and provide them with credentials. This trend fits with what Lucena et al. (2008) call the "dominant image" in American engineering: the need to 
prepare for global competitiveness. ${ }^{\text {ii }}$ Yet this framing of the global situation, and the role of higher education in the face of it, need not hold sway. A critique of the economistic view holds that "more complex, self-reflective, organic ways of thinking will be vital in re-shaping education so young people are better equipped for the complexity, paradox and unpredictability of life in the twenty-first century." "iii Training students to think critically about this complexity shifts their mindset from one of competition to one of collaboration, which allows them to engage productively with international and local peers, instead of simply outstripping or defeating them in a global struggle for resources. Engagement, then, represents a radical alternative model for higher education, but moving toward that alternative requires overcoming both structural impediments within the university and conceptual impediments within students and faculty.

Service learning and community engagement (SLCE) research and work have emerged as a possible means to pursue this alternative, engagement-based model. For this alternative to be viable, however, it has to overcome a number of challenges, which we can think of as a set of related-but-distinct silos. While traditionally silos in the academy are viewed as divisions between disciplines, we have come to see that individual mindsets also serve to separate people into silos. These silos include the mindset of students, bent on either the pursuit of job credentials or on a quest to save the world, the mindset of faculty, focused on producing cuttingedge research and competing with peers, and the separation of the university from the knowledge located in local and global communities. ${ }^{\text {iv,v,vi,vii,viii }}$ To begin breaking through these silos, we have developed a co-curricular approach that creates a continuum of engagement and learning for students, faculty, and communities. This continuum aims to redirect students and faculty away from the drive to solely produce a competitive product (or trophy) and toward an appreciation of the ongoing process of engagement. ${ }^{i x, x}$, xi To construct this continuum, we draw on the idea of an intellectual apprenticeship. The students in this model serve as the apprentices, while the faculty, along with community partners and other colleagues, act as mentors in a guild of "artisans" dedicated to putting useful knowledge into action.

The goal of this paper is to share our experience with this apprenticeship approach, including its achievements and challenges, as an example with the hope that others might borrow what they find useful and add what they think is missing. The paper proceeds in three parts. First we outline the silos that we see as the most important obstacles to effective SLCE work in the university. We move on to describe the apprenticeship, starting with our shared philosophy and continuing with the pedagogy, divided into five stages. We then briefly articulate what we see as the evidence that our approach is meeting with some success, and the ongoing challenges that we face.

\section{SILOISM}

The intellectual apprenticeship that we propose serves to break down silos both within and outside of the university. These silos impede the equitable sharing of knowledge and understanding that can enable a more just world, rather than a more stratified one. Here we explore three kinds of silos: those within institutions (limited here to those between faculty), those between faculty and students, and those between the university and the community. Furthermore, these silos represent entrenched ways of acting and ways of thinking, which makes them difficult to breach. The silos within institutions are well known. They divide the university into distinct disciplines (and schools), leaving little room for cross-specialty collaboration. As 
Handler argues these disciplinary divisions have little to do with specific intellectual problems or societal challenges. ${ }^{\text {xii }}$ Rather, the dividing lines result from the historical process of institutionalization and specialization. Despite being, in some ways, a historical accident, this increasingly specialized departmental structure guides the education, hiring and rewarding of the faculty. As a result, faculty focus on gaining the recognition and respect of colleagues in their department and in their discipline, even as they compete with these colleagues for promotion and funding. ${ }^{\text {xiii }}$ There is little incentive for faculty to reach outside of their home department and to collaboratively engage and generate knowledge across disciplines. Even the interdisciplinary programs that have become more common on campuses do not create extensive cross-discipline ties. Despite the many calls for interdisciplinary work, the work of what Gregorian calls the 'generalist academic' is not what earns tenure and promotion. ${ }^{\text {xiv }}$ Further, interdisciplinary majors, an important mechanism for discipline-crossing work, remain largely marginal to the university. ${ }^{\mathrm{xv}}$ This marginality applies especially to SLCE scholarship, which often falls to faculty outside of the traditional tenure track. Many universities have programs and centers focused on SLCE, but few create incentives for faculty to work collaboratively with communities, let alone other faculty from different disciplines. As a result, institutional siloism often prevents faculty from reaching outside of their department to engage with communities different than themselves.

The second type of silo exists between faculty and students. Despite the fact that the university exists to bring these two groups together, they remain in separate worlds because they strive for goals that have little to do with engaging each other. Faculty at research-driven institutions often focus on their research work, to the neglect of their teaching. This point is all too familiar, but unfortunately, it still rings true. A new twist on this neglect, however, comes from economic pressures. Higher education at all levels is feeling the pressure to generate revenue, and the rhetoric surrounding this economic pressure emphasizes maximizing this revenue, through teaching more classes with more student throughput and using temporary

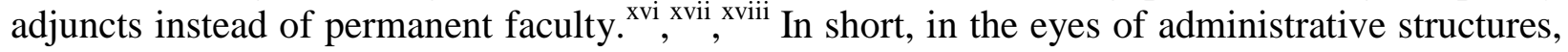
students too easily become revenue-generating units, not learners. Indeed, new budgetary models (such as the impending model at the University of Virginia) have the departments compete for students, because the funding for the department depends upon how many students they teach.

Students, for their part, increasingly see their higher education as a means and not as an end. They come to get the training and credentials that they perceive will give them a competitive edge when seeking employment. Too often, for these students, developing the ability to think critically plays second fiddle to preparing for the job market. Labaree and others have described this emphasis as the pursuit of private goods over public goods. ${ }^{\text {xix }},{ }^{\mathrm{xx}}$, ${ }^{\mathrm{xi}}$ And one can argue that such students have good reason to see things this way, given the tremendous economic pressure and fiscal constraints that they are under - specifically, the mountain of debt they are accumulating. Given this mindset, students too often turn to SLCE as a résumé-booster, rather than as an important learning experience, one that enhances the ability to think critically. Or, if they do see it as a learning experience, they often understand it in instrumental terms, as a way to acquire "global" or "intercultural" skills that, again, would serve them well on the job market. ${ }^{\text {xii }}$ xxiii xxiv Again, such an instrumental view focuses on individual advancement (private goods) over the demands of citizenship and over moral duties to others (public goods), when both kinds of goods are necessary.

Finally, the third silo separates higher education from local and global communities. Many of the aforementioned economic pressures (e.g. money and time) create little incentive for universities, faculty and students to engage communities deeply. Indeed, at times universities are 
like islands, separated from their immediate environment, often with numerous universitycommunity tensions, colloquially referred to as "town and gown" conflicts. ${ }^{\mathrm{xxv}}$ Yet despite this separation, two different kinds of pressures push both students and faculty to engage with communities, especially internationally. The first is the desire to acquire "global" skills, while the second is the desire to "give back." Communities are aware of these pressures and perceive that institutions are seeking "to improve [the] image of the campus and to obtain access to research sites and contacts."xxvi Such thinking on the part of the universities could be expected, given the economistic / individualistic sentiments prevalent in the enterprise of higher learning. The mindset that communities are there to serve the higher purpose of the institution and the needs of students and faculty often results in SLCE engagements that can be one-sided and extractive or transactional in their nature. ${ }^{\text {xxvii }}$ Such activities often do not foster what Clayton et al. (2010) term "transformative relationships" but rather maintain clear divisions between higher education and surrounding communities.

As noted above, the fear of global competition has pushed students to acquire credentials and skills that will serve them well on the job market. Given this concern, many students seek to acquire skills that they might use in international business, and SLCE has become a means to acquire them. SLCE, in this thinking, can foster such "global" skills as linguistic and intercultural competence. In turn, this potential result of SLCE has motivated faculty, administrators, and other stakeholders in higher education to develop SLCE programs that might attract the best students (especially those who can pay their own tuition). Given this motivation, it is not surprising that these programs often focus entirely on the benefits of these programs to the students and may not even have a means to evaluate the impact on communities. ${ }^{\text {xxviii }}$ Thus, while the students are traveling to communities (again, local and global, though global is often more attractive as it seen as more exotic), their motivation and mindset keeps them siloed off from those communities, unlikely to engage them fully. ${ }^{\text {xxix }}$

Some students, however, engage in SLCE with the goal of service at least partially in mind, not just to build résumés or develop marketable skills. These students aim to "give back" to others whom they see as being in need of their help. ${ }^{\mathrm{xx}}$ Yet despite this service-oriented mindset, many students approach their work as a form of charity, as a solution that they are bringing to a community in need. ${ }^{\mathrm{xxx}}$ Butin (2010), for example, argues that students too often neglect the extreme imbalance of power relationships that allow them to travel to distant communities, often wielding resources and authority well beyond what their experience merits. ${ }^{\text {xxii }}$ The students are, in effect, blind to their own cultural location of privilege and power in a way that keeps them separate from the communities they visit. Indeed, one student group in South Africa told a group of our students, "Don't bring us your electricity. Sit with us in the dark, and we will tell you what we need." Even this quotation presumes that the relationship is posited on "need," but it nicely points out the ease with which SLCE participants presume that they come bringing answers. This orientation blinds them to the knowledge and capabilities of the communities they visit, siloing them off from those communities.

\section{InTElleCtuAl APPREnTiCeShip AS A CONTINUUM OF LEARNing}

The "intellectual apprenticeship" we describe aims to change mindsets of both students and faculty, with the larger goal of reshaping the relationship between the institution and communities near and far. It would be immodest to claim that we, working with our community partners and colleagues, can make radical changes in mindsets, but the aim of this 
"apprenticeship" is to contribute to the process by preparing students to cross boundaries, engage those communities and to be open to the exchange of knowledge. Before they can do this, however, they have to be prepared. While they are doing it, they must be mentored. When they return and process their experience, they must be supported. The process, then, takes a great deal of time and energy. In addition, it requires a consistent and integrated pedagogy. It requires something analogous to an artisanal apprenticeship. We therefore have developed a continuum of learning that serves to shape both the students moving through it and the faculty and community mentors contributing to it.

This metaphor of apprenticeship suggests three important aspects. First, we spend a great deal of time with students, before, during and after their SLCE experience, crafting their learning. Second, the students learn not simply by listening in class and then trying to conduct the project, but also by observing the faculty and community partners model the behaviors needed for ethical and effective engagement, whether they engage with students, fellow faculty or with community members, within and without the classroom. The third is that the members of the "guild" share authority — with each other and with partners outside of the academy — in shaping the students' learning and in cultivating their skill.

\section{Philosophical Principles}

This continuum grows from a consistent philosophy developed over the years of our work and shared amongst the participating faculty. This philosophy undergirds not only our teaching, but also the alternative point of view that we hope will break down silos. It can be summarized as the "three Rs:" respect, reciprocity, and relationship. Beginning with respect, we hold that every person has a store of important knowledge to share. Given this knowledge, and their inherent human dignity, we should seek to understand others before making ourselves understood. This initial principle is a direct challenge to the common conception of SLCE as a form of charity, because it precludes simply coming in and "fixing" things that are wrong. It suggests, rather, that we adopt an asset orientation: we come looking for strengths to which we can add our experience and knowledge.

Reciprocity, the second principle, follows directly from this first one. If our interlocutors have knowledge and are worthy of respect, then when they share their knowledge (and time) with us, we must see it is an important gift. We, too, have something to offer in exchange, but we must understand that our gift is offered in a spirit of reciprocity, not charity.

The last of these three pillars is relationship, and it is surely the most difficult but most important. We start by considering the connections that already exist. We presume that we are already connected to communities, both local and global, and this premise implicates us in what goes on in those communities. SLCE then becomes not a one-time exotic vacation, but an exploration of pre-existing connections. Further, we believe that these connections are (almost always) grossly unequal. When we think of creating a relationship, then, we mean that we seek to create a more just and equitable relationship, one that intentionally incorporates the elements of respect and reciprocity and that draws strength from diverse perspectives. We are not naïve about the power imbalance that exists in most, if not all, SLCE projects, so we do not want to suggest that this relationship can be equal. In many international SLCE (ISLCE) projects, for example, the community partners might have a much more difficult time coming to us than we have going to them. But our goal is to foster ongoing relationships, ties between the university and the community that can grow and last well beyond the students' time at the university. 


\section{Putting Principles into Action}

We aim to have these principles undergird all of our interactions with students, faculty, and communities; they provide the basis for our continuum of learning. This continuum begins with the students and spreads out over five stages, described below. Each of these stages, however, is informed by three practices: creating cognitive dissonance, collaborating with other faculty, and involving community partners. These practices, which support and help further our philosophical principles, provide a common basis for the stages.

The first practice, creating cognitive dissonance, is a pedagogical strategy that ensures that students are open to the profound demands of pursuing respect, reciprocity, and relationship. While some students come to SLCE work with an attitude of engagement, many students' common sense understanding of SLCE work is one of charity, or even simple résumébuilding. ${ }^{\text {xxxiii }}$ Over a length of time, and with increasing intensity, we seek to challenge the students' frames of reference. ${ }^{\text {xxiv }}$ We seek to create what Ken Bain (2004) calls "expectations failures" by exposing the students to cases, theories, and situations in which their expectations the common sense of their particular silo - fail to work satisfactorily. ${ }^{\mathrm{xxxv}}$ This failure creates cognitive dissonance, which opens the students up to an alternative way of thinking. At this point we give them room to restore and recover from this shock, while offering them our alternative point of view. The process takes place repeatedly over the course of eighteen months or more, moving through five stages, described below. By continually challenging students and then letting them recover and make sense of the challenge, before challenging them again, we gradually build up a different way of thinking about SLCE.

The second key element of the continuum is the collaboration between faculty. The continuum of collaboration ideally involves a diversity of faculty: across disciplines and schools and on and off of the tenure track. From the start, our major programs, ESAVANA $^{\mathrm{xxxvi} \text { xxxvii } x x x \text { viii }}$, ${ }^{\mathrm{xxxix}}$ and the UVA-Guatemala Initiative, ${ }^{\mathrm{xl}}$ have been interdisciplinary and have required that the faculty reach consensus over program development, course planning, and student advising. At different times the fields represented have included Environmental Science, Education, Anthropology, Medicine, Engineering, Nursing, and Architecture. Simply bringing together these different actors does not, however, create the depth of collaboration that we seek. We do not simply divide up lecture topics according to discipline. We try to model collaboration in and out of the classroom. When one person lectures or leads discussions, the others actively listen and respond. They raise questions or analyze a topic from a different disciplinary perspective. We follow the advice of Richard Feynman, to see inquiry as requiring constant questioning of our theories and methods, to always be open to other ways of approaching a topic, of asking a question, or even just of perceiving and being in the world. ${ }^{\text {xli }}$ Coming out of the rigidly disciplinary structure of the university, and being older and well settled in our points of view, this demand for openness can be the most challenging aspect of the work. Thus, even our frames of reference are challenged.

By actively seeking collaboration, by sharing our understanding, and by allowing that understanding, and even our frames of reference, to be challenged, we seek to model our principles for the students. We hope that this modeling serves to inculcate an understanding of what ethical community engagement requires. This modeling extends to the third component of our continuum of learning: the involvement of authorities from outside the university. These include foreign academic colleagues, community activists, and community partners, and, 
consistent with our principle of respect, we present them as bearers of important knowledge. We purposefully include opportunities for these knowledge authorities from outside the Academy to have access in the classroom. Through these interactions and through our interactions with community members and international colleagues, our core group of transdisciplinary faculty aim to model the types of responsible engagements that we expect of our students as they work with communities outside of the university.

\section{Five Stages of Apprenticeship}

Our interactions with SLCE students occur across five different stages, with each stage exposing them to theories, methods, and stories from different disciplines and different perspectives, including perspectives from outside the university. Further, each step involves faculty collaborating closely and continuously. Each stage challenges the students' frames of reference as much as possible, while still giving them the opportunity for restorative practice so that they can process what they experienced without being overwhelmed. These five stages of pedagogy are presented using a series of metaphors, but taken together, the stages form a continuum of learning, in effect an intellectual apprenticeship, which takes place over a minimum of eighteen months, and possibly much longer. These stages are more than a series of classes; they form an integrated experiential education. We have arrived at this particular form of the apprenticeship through trial and error and have created it so as to support and to not overwhelm all of the stakeholders in this joint educational venture - students, community and faculty.

\section{The Snow Globe $e^{x l i i}$}

The first stage we call the "Snow Globe," and it most frequently takes place in introductory classes. These introductory courses challenge students ' frames of reference through exposure to theories, stories, and case studies (from a variety of disciplines) that do not fit with their everyday experience. It is as if students have been living in a large snow globe (i.e., an academic bubble) where they had not needed to see anything differently. Then, faculty and/or community partners "shake" the "Snow Globe" through this exposure to new points of view, and suddenly the students are surrounded by things they cannot immediately process from their old perspective. We then use class discussion, both plenary and small group, and writing to help the students to process these new insights and perceptions gained. Through this process, we begin to chip away at disciplinary silos, as well as personal silos, ones that the students are not often aware of before such an exercise. For example, we have students watch an early film on the "play pump" development project before coming to class. ${ }^{\text {xiii }}$ Usually, they watch the program and come to class energized by the idea of a development project that seems so perfect. We then show them a later film about the project, one that demonstrates the many problems with the project. ${ }^{\text {xliv }}$ Students then come to realize that the project made sense to them from their own cultural perspective - and indeed to foundations in the U.S. - but that perspective did not take into account many factors that were important on the ground. The students' reaction is always strong, and sometimes quite emotional, but as they process the experience, they come to see the limitations of their own point of view. 


\section{Water Wings}

The second stage we call the "Water Wings." Through an intersession course at UVA and shortterm study abroad courses in Guatemala and southern Africa, both of which are intensive and experientially based, the students begin to interact with people from outside of the University silo. For the intersession course, foreign academics, students, and community activists come to grounds not only to engage with students but also to do so as collaborating knowledge authorities. We create a facilitative environment in which interdisciplinary student teams receive close mentoring from our foreign co-instructors and us as they develop hypothetical project proposals that could, depending upon their quality, actually be implemented. Over a period of seven years, we have had nearly a dozen collaborative ISLCE projects developed as part of the intersession program, after heavy modifications, go on to actually be implemented in some form. For example, two first-year students in a January intersession course developed a project that would reduce deforestation through the use of improved stoves. The students then went on a study abroad trip, where they saw an example of these stoves, and over the next year, developed a service learning proposal to improve these stoves. The students, as part of an interdisciplinary student team, then traveled the next summer to implement it in region. The project has flourished since then, as more stoves have been built, and the students have gone on to publish one article in a peer-reviewed journal and submit another. ${ }^{\text {xlv }}$

For the shorter-term study abroad courses, the students travel with foreign students and they visit sites involving the faculty's on-going community engagement work. In effect, this stage provides the students with an opportunity to practice (swimming) with close supervision, not unlike youth that are learning to swim and heavily reliant on water wings to support their efforts. Students are mentored through the process of engagement and are introduced to rather than imposed upon community partners. These study abroad opportunities provide students and community members and potential project partners the opportunity to 'test drive' each other while not having the pressure to commit on the spot. As faculty with pre-existing relationships, we communicate, in advance and in a transparent fashion, with our community partners that we have young students who wish to learn - who are seeking knowledge - and ask for permission from our community contacts to engage with them as part of this process. This stage, then, serves to break down the silo of university/community, demonstrating that knowledge and the requisite knowledge authorities often reside outside of the academy. It also serves to break down the students" "save the world" silo, as they begin to recognize and respect knowledge from outside the academy and come to realize that they have to take a collaborative, not a charitable, approach. Furthermore, it models the importance of voice and the principals of respect, reciprocity and relationship.

\section{Summer Camp}

Once the students have mastered their Water Wings experience, they are ready for "Summer Camp." This is the next step in which the students secure funding to conduct some form of community engagement work, at home or abroad. We liken this stage of our approach to our students heading off to an extended stay away learning experience where there is always adult supervision, if you will, but enough freedom for the students to have to wrestle with the complications of SLCE work, such as dealing with a plan that had been designed without enough understanding of the context that, as a result, is not working in the field. The students have to sit 
down with their colleagues and partners, which include in-region faculty and TAs, practitioners, and community members, to make collaborative, real time adjustments in the field. This forces the students to address the really hard life question of "now what?" This stage serves to break down silos between faculty and students and between the university and the community. The faculty and community members continue to act as mentors, analogous to the role of artisans instructing apprentices, but the students begin to practice their craft with increasing autonomy. In this situation, the faculty continue in the roles of master craftsmen, the students have the opportunity to not only engage with the true artisans, the community practitioners, but to live up to and meet their expectations. An example of this was when one student group working on an international community sanitation project found that their project plan, which had been developed in response to expressed needs from the community over the six months leading up to the trip, ran into difficulties. In response, the team had to reconfigure the project on the spot in collaboration with and benefitting from the broader community and their knowledge. In other words, despite the extensive preparation and pre-trip discussion with the community, the team still found they had to fundamentally rework their project and could only do so jointly on the ground with the community. ${ }^{\text {xlvi }}$

\section{Decanting the wine and then letting it breathe...}

The fourth stage sees the students returning to campus and processing their experience: they are, in effect, "decanting the wine and then letting it breathe." We use the metaphor to show that the students have all of the ingredients and have brought them together under the "right" conditions, yet it is not yet mature. Through the process of aeration, of bringing forth what has been bottled up and cut off from oxygen, the wine it attains its full essence. To achieve this we offer intensive faculty mentoring during which students make sense of their experience from personal, cultural, and political-economic perspectives. They make sense of this experience by reflecting on it and analyzing how their actions and understandings stemmed from their socio-cultural location. This reflection takes place most often in individual or small-group independent study, but we have experimented with a co-taught seminar course that brought together different student project teams to share their experience and jointly to develop a broader understanding of the process of SLCE. This personal reflection and peer review and sharing has proved quite helpful for the students. Many developed a firmer understanding of their own socio-cultural location and the work of community development. Further, a number took advantage of the repeated interactions with faculty and peers to write and iteratively revise articles about their work. To return to the decanted wine framework, the students did not simply return from the field and jot down their results; their ideas matured through being exposed to others, like wine aerating through exposure to oxygen. By placing the emphasis on metacognitive learning through reflection, this stage serves to break down the students' silo of job-skill orientation. It also gets them to understand better their connections to the community, breaking down the silo that separates them.

\section{The Hand Off}

The final stage of this process is the "handoff." Students, who were once on the receiving end of the handing off of new knowledge, are now guardians of co-generated knowledge. These students therefore have the opportunity and the responsibility to share this with community partners, with other students, with the university, and with the SLCE field. The metaphor of a 
handoff, from relay races at track and field meets, signifies what goes into the effective communication, transmission and dissemination of knowledge. The metaphor gets students thinking about their role as holders of knowledge that has been entrusted to them to carry. When thinking about this exchange of knowledge, one can liken it to what goes into an effective handing off of the baton on the track: the person who has been entrusted to carry the baton is part of a team and is responsible for arriving at the place and time that those to whom they intend to pass the baton are expecting it. They have the responsibility to place the baton/knowledge firmly into the grasp of those that they intend to receive it, and they cannot let go of the baton until they are sure that the recipients have a firm grasp of it and are ready to run with it themselves. Students, therefore, must think about their role as holders of knowledge that has been entrusted to them to carry.

This last stage serves to break down the silo of disciplinary-specific communication of knowledge between different constituents. It makes knowledge accessible, and not just for those privileged enough to be within the academy. At the same time, it helps students understand that they are part of something larger, that a "project" is not simply their individual achievement, but rather an ongoing, joint endeavor. They come to see that they now are forever connected, that they are part of a relationship.

Like the relationship, the handoff is ongoing. Students not only hand off their understanding to the next student teams, but they also contribute to all five of the stages, as upperclass members, as graduate students, and as alumni. They return to class to talk about their experience, agitating the snow globe a bit. They serve as TA's or advisors as the new students try out their water wings. They serve as in-the-field mentors or other resources while the students go to 'summer camp,' and they can offer advice and peer mentoring while the returning students are letting their wine breathe. In assuming these positions of authority, the students further break down the silo separating faculty and students. Where the students had been a subordinate role, they suddenly become peers and collaborators with the faculty. They are thrust into the role of teaching, but as they do this, we ask them to reflect on where they were at this stage of their own work. They realize what they were missing at this stage. This reflection not only helps them recognize their own growth, but it also cultivates a sense of empathy with the new cohort of students.

\section{Summary of the Intellectual Apprenticeship}

Looking back on these five stages of intellectual apprenticeship, we see three key elements. First, the continuum of learning is crucial to successful student learning and to the breaking down of silos. This continuum stretches across the different stages of conducting SLCE. Students need to be well prepared before beginning SLCE; they need to be mentored carefully during the work; and they need to be given the space and support to process their experience fully afterwards. We maintain that by challenging their frame of reference throughout the process, we get them to think of this effort as an iterative process, not a simple recipe to create a pre-determined product. Rather, they constantly have to question and to reflect on the process that they are involved in and on their role in the larger enterprise. Along the lines of Gregorian (2004) they are moving from mindless consumers and processors of knowledge and wisdom, to purposeful critical thinkers who are able to make "connections among seemingly disparate disciplines, discoveries, events, and trends — and to build bridges among them that benefit the understanding of us all."xlvii 


\section{WHY WE BELIEVE IT WORKS...}

We assert that our intellectual apprenticeship approach to chipping away at those silos is gaining ground. We provide the following evidence to support our assertion: the development of an interdisciplinary suite of collaboratively taught coursework and the collaborative knowledge produced by the students whom we have engaged. From 2006 to present, a group of interdisciplinary faculty developed a suite of co-taught courses that were offered during regular semester sessions, intensive January intersessions and during summer study abroad (see Appendix A). Students from these courses have gone on to conduct mentored SLCE participate in the "Summer Camp" stage — in many different countries, especially South Africa and Guatemala. On their return, they have worked through the stage of "letting their wine breathe" and have been able to "handoff" their co-generated knowledge, not only to other students, but also to the field more broadly. They have presented results from their work at conferences of six different professional associations, xlviii and they have published nine articles in peer-reviewed journals. ${ }^{\text {xlix } 1 \text { li lii liii liv lv lvi lvii }}$

Within our institution, students whom we have engaged over the past decade have been central to several student-led efforts to help craft learning experiences along the lines of what Hugh Sockett has called "reason-in-action - that which connects wisdom, tacit knowledge, plans, techniques, ideals, and justification within experience." "viii These have included the Engineering in Context concentration, the development of expanded course offerings in the STS program in our School of Engineering and Applied Science and also the development of the interdisciplinary Global Development Studies program in our College of Arts and Sciences. Alumni of our approach have also been integral in disseminating their knowledge/lessons that have emerged from these collaborative SLCE activities in our suite of interdisciplinary courses across our schools of architecture, the College of Arts and Sciences, Commerce, Education, Engineering, Medicine and Nursing.

Outside of the formal classroom setting, our experienced students, both undergraduate and graduate, have featured prominently in extra-curricular programming run by our offices of community engagement and international studies. More importantly, they have served as student 'elders' as it were, who have the responsibility to go out and recruit the types of new students that they believe could best maintain the relationship with their community partners. Perhaps these students' active role is more a reflection of the particular culture at our institution, which heavily emphasizes student autonomy, but our student alumni have gone on to occupy leadership positions in student governance organizations inside and outside of the institution. These include orientation of incoming students, leadership of student contracted independent organizations such as Engineering Students Without Borders, Alternative Spring Break, the Global Development Organization, Student Entrepreneurs for Economic Development, and Sustain-aunity. In the case of ESWB, our students have held leadership positions from 2005 until present.

Perhaps the most telling example of the impact of our approach can be relayed through an interaction that one of our students who was involved with developing small scale methane biodigesters in rural South Africa had with a senior administrator. After having gone into the field with our students for an on-site inspection of an implemented biodigester, the administrator began to get very excited at the possibility of up-scaling the approach. There was discussion about improved design-and-build activities back on campus, with improved products ready to ship off to this remote rural area. Before anything could be said by the faculty mentor who was present, one of our trained undergraduate students stopped the excited administrator. Quite 
simply and humbly, she said "You don't understand. We cannot design the solutions in the vacuum of a far removed lab. We have to do it here, with our partners with what they have - it has to come from here in order for it to work." We view this example of a student who has taken the charge of responsible guardian of the co-generated knowledge seriously as evidence that this intellectual apprenticeship is producing new artisans of engaged scholarship.

\section{Ongoing Challenges}

The biggest challenge to our approach, of course, is the persistence (and reinforcement) of the silos discussed here. In many ways, SLCE scholarship is swimming against the tide of higher education. The dominant economistic and individualistic view of higher education does not leave much room for pluralistic border-and-discipline-crossing understandings of knowledge. Thus, the administration and fellow faculty often negatively view faculty who do this work as "generalist academics." lix Further compounding this negative perceptions is the structural problem that faculty involved with SLCE are often outside of the traditional tenure track, a position likened by Robert Reich (2013) to that of 'itinerant workers. " ${ }^{\text {, }}$ Many have articulated a need for higher education to allow for the emergence of more pluralistic forms of learning, learning that is possible using SLCE approaches. However, as Butin cautions "the very institution that service-learning advocates are trying to storm, in other words, may drown them.",xi

\section{A Possible Way Forward?}

Our approach to experiential education for SLCE, for which we have used the metaphor of an intellectual apprenticeship, is built on the core values of the three R's - Respect, Relationship and Reciprocity. Based on these values, it has as its goal the collaborative and equitable cogeneration of knowledge between students, faculty and communities. By preparing students for this work, we hope to contribute to breaking down the silos - both institutional structures and individual and disciplinary mindsets - that prevent universities from engaging communities in an ethical, sustainable way. By demonstrating that this is not a solitary, individual activity - just as working in the 'real world' is not an solitary endeavor but often a collective exercise, especially for scientists and engineers (whether in the lab, in the boardroom or out on the field site), we contend that we, in our own small way, are indeed chipping away at the silos of that prevent transformative engagement, learning and knowledge production.

\section{ACKNOWLEDGMENT}

The authors wish to acknowledge the support of resources provided by Terence Y. Sieg, Joe and Diane Thomas, John and Dudley Macfarlane, Scott McDonald, Jeff and Darlene Anderson, Susannah Rouse, Bob Tinker, Mike Fetsko, the Fair Play Foundation and the Barley Scholars Program. The authors acknowledge support provided by the Office of the Vice Provost for Academic Affairs and their Jefferson Public Citizens and Community Based Undergraduate Research grant programs and the Office of the Vice Provost for Global Affairs, both at the University of Virginia. The authors would like to recognize the in-region logistical support of Ms. Lisanne Frewin, Ms. Beverly Terry, and Mr. Cornelius Hagenmeier. Finally the authors wish to thank the three anonymous reviewers for their insightful comments and constructive feedback that improved the manuscript. 


\section{APPENDIX A: COMPONENTS AND ACHIEVEMENTS}

\section{Courses Offered}

\begin{tabular}{|c|l|c|}
\hline Department & Course Title & Session \\
\hline GDS / ENGR & Useful Knowledge and Its Impact on Local and Global Communities & RS \\
\hline EVSC / STS & Ethics, Protocols and Practice of International Research & JT \\
\hline ENGR & Engineering in Community Settings & RS \\
\hline GDS & Development on the Ground & RS \\
\hline STS & Cross Cultural Engineering & RS \\
\hline GDS & Developing Community Projects & RS \\
\hline EVSC / ANTH & UVA in Southern Africa: People, Culture \& Environment of Southern Africa & SA \\
\hline GDS & UVA in Guatemala: An interdisciplinary Exploration of Public Health & SA \\
\hline
\end{tabular}

Table 1: The home department, title and academic session of our suite of Interdisciplinary course offerings related to service learning and community engagement. Where: GDS - [a global studies program]; ENGR - General Engineering; EVSC - Environmental Sciences; STS - Science, Technology and Society; ANTH - Anthropology; RS - Regular Semester; JT - January Term Intersession; SA - Summer Study Abroad.

\section{Collaborators: Faculty, Graduate Students and Foreign Colleagues}

The list of people who have contributed to the development of this intellectual apprenticeship over a period of more than a decade is very long, over two hundred people. We therefore include here the major contributors, people who have co-taught with us or helped design our courses.

UVA Co-Instructors: David Burt, Doris Greiner, Loren Intolubbe-Chmil, Diane Hoffman, Paxton Marshall, Jessica Ohana González, Michael J. Smith, Hanan Sabea, Carol Anne Spreen, Clare Terni, Susanna Williams.

TAs: Caroline Berinyuy, Augusto Castilho, Lyndon Estes, Ethan Heil, Ingrid Hakala Isin, Hlekani Kabiti, Martin Kigozi, Chrissie Monaghan, Fred Mphephu, Duncan Nengwenani, James Ngundi, Bukiwe Ntwana, Gadisi Nthabeleni, Siddhartha Pailla, Matthew Pawlowicz, Audrey Raedani, Elias Ramarumo, Carolina Ramoa, Ivan Remane, Andre Ribeiro, Lavhelesani Simba, Keir Soderberg

US and Foreign Colleagues: Harold Annegarn, Leonardo Abilio Antonio, Thomas Blaser, Chris Colvin, Claudio Cuaranhua, Ken Dabkowski, Tashi Dekyid, Palsang Drachung, Claudia Ford, Joseph Francis, Varkey George, David Germano, Krishna Gurung, Jean Pierre Hitimana, O.G.S.O. Kgosidintsi, Shuaib Lwasa, Sophie Mahoko, Elizabeth Makule, Edwin Makungu, Musa Rally Manganye, David E. Martin, Hiskia Mbura, Kelebogile Mfundisi, Tumela Errol Mudau, Gitile Naituli, Martha Nalubega, Vhonani Netshandama, Peter Omara-Ojungu, Shirley Pendlebury, Stuart Piketh, David Pratt, Natasha Ribeiro, Amidou Samie, Santiago Sitay, Thakhani Takalani, Barbara Tapela, Matthew Therrell, Kaizer Thomas, Wayne Twine, Salim Vally, Jan Vermeulen, Suzanne Walther, and Masingita Edna Zwane. 


\section{REFERENCES}

${ }^{\mathrm{i}}$ Gregorian, Vartan. "Colleges must reconstruct the unity of knowledge." The Chronicle of Higher Education 50, no. 39 (2004): B12.

ii Lucena, Juan, Gary Downey, Brent Jesiek, and Sharon Elber. "Competencies Beyond Countries: The ReOrganization of Engineering Education in the United States, Europe, and Latin America." Journal of Engineering Education 97, no.4 (2008): 433-447.

iii Gidley, Jennifer M. "Futures of Education for Rapid Global-Societal Change." There's a Future: Visions for a Better World. (2012): 395-419.

${ }^{\text {iv }}$ Labaree, David F. "Public Goods, Private Goods: The American Struggle over Educational Goals." American Educational Research Journal 34, no. 1 (1997): 39-81.

' Osman, Ruksana, and Nadine Petersen. "Students' Engagement with Engagement: The Case of Teacher Education Students in Higher Education in South Africa." British Journal of Educational Studies 58, no. 4 (2010): 407-419.

${ }^{v i}$ Keith, Bruce, and Nicholas Babchuk. "The Quest for Institutional Recognition: A Longitudinal Analysis of Scholarly Productivity and Academic Prestige among Sociology Departments." Social Forces 76, no. 4 (1998): $1495-1533$.

vii Tuttle, Brad, and Jesse Dillard. "Beyond Competition: Institutional Isomorphism in US Accounting Research." Accounting Horizons 21, no. 4 (2007): 387-409.

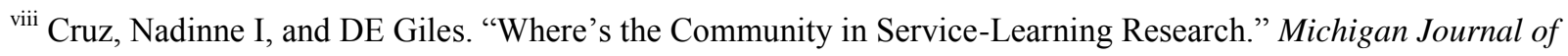
Community Service Learning 7, no. 1 (2000): 28-34.

ix Walther, Suzanne, Loren Intolubbe-Chmil, and R.J. Swap. "Promoting Sustainability Through Enhancing Resilience: Transdisciplinary Teaching and Learning in the Cross Cultural Context of ESAVANA.” In Teaching Sustainability: Perspectives from the Humanities and Social Sciences, edited by Wendy Petersen-Boring and William Forbes. Stephen F. Austin University Press, 2014.

${ }^{\mathrm{x}}$ Intolubbe-Chmil, Loren, Carol Anne Spreen, and Robert J. Swap. "Transformative learning: Participant perspectives on international experiential education." Journal of Research in International Education 11, no. 2 (2012): 165-180.

${ }^{x i}$ Brown-Glazner, Rachel, Veronica Gutierrez, and Ethan Heil. "Engaging people, not projects: Redefining the standards of service-learning through a community led project in Tshapasha, South Africa," in Virginia Policy Review, 3, no. 3 (2010): 5-9.

${ }^{\text {xii }}$ Handler, Richard, "Disciplinary Adaptation and Undergraduate Desire: Anthropology and Global Development Studies in the Liberal Arts Curriculum." Cultural Anthropology 28, no. 2 (2013): 181-203.

xiii Keith B., et al., "The quest for institutional recognition: A longitudinal analysis of scholarly productivity and academic prestige among sociology departments," 1495-1533.

${ }^{\text {xiv }}$ Gregorian, Vartan. "Colleges must reconstruct the unity of knowledge." The Chronicle of Higher Education 50, no. 39 (2004): B12.

${ }^{x v}$ Handler, "Disciplinary adaptation and undergraduate desire: Anthropology and global development studies in the liberal arts curriculum," 181-203. 


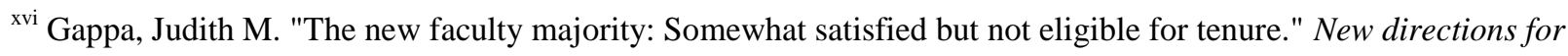
institutional research 2000, no. 105 (2000): 77-86.

${ }^{\text {xvii }}$ Bettinger, Eric P., and Bridget Terry Long. "Does cheaper mean better? The impact of using adjunct instructors on student outcomes." The Review of Economics and Statistics 92, no. 3 (2010): 598-613.

xviii Johnson, Iryna Y. "Contingent Instructors and Student Outcomes: An Artifact or a Fact?" Research in Higher Education 52, no. 8 (2011): 761-785.

${ }^{\text {xix }}$ Labaree, D. F., "Public Goods, Private Goods: The American Struggle Over Educational Goals," 39-81.

${ }^{\mathrm{xx}}$ Southerland, Sherry A, and Todd Hutner. "The 'Problem' of Inquiry: The Divide between Educating for Credentialing and Educating for a Democracy," in Inquiry in the Classroom: Realities and Opportunities, by Eleanor Abrams, Sherry A Southerland, and Peggy Clohessy Silva, (Charlotte, NC: Information Age Publishing, 2008), 157-165.

${ }^{\text {xxi }}$ Labaree, David F. "Resisting educational standards." Phi Delta Kappan 82, no. 1 (2000): 28-33.

${ }^{\text {xxii }}$ Handler R., "Disciplinary adaptation and undergraduate desire: Anthropology and global development studies in the liberal arts curriculum," 181-203.

xxiii Tomlinson, Michael. “"The Degree Is Not Enough': Students' Perceptions of the Role of Higher Education Credentials for Graduate Work and Employability.” British Journal of Sociology of Education 29, no. 1 (2008): 4961.

${ }^{\text {xxiv }}$ Kasworm, Carol E, Lorilee R Sandmann, and Peggy A Sissel. “Adult Learners in Higher Education.” Handbook of Adult and Continuing Education (2000): 449-463.

${ }^{x x v}$ Mayfield, Loomis. "Town and Gown in America: Some Historical and Institutional Issues of the Engaged University." Education for Health Change in Learning \& Practice 14, no. 2 (2001): 231-240.

${ }^{x x v i}$ Sandy, Marie, and Barbara A Holland. "Different Worlds and Common Ground: Community Partner Perspectives on Campus-Community Partnerships.” Michigan Journal of Community Service Learning 13, no. 1 (2006): 30 .

xxvii Clayton, Patti H, Robert G Bringle, Bryanne Senor, Jenny Huq, and Mary Morrison. "Differentiating and Assessing Relationships in Service-Learning and Civic Engagement: Exploitative, Transactional, or Transformational.” Michigan Journal of Community Service Learning 16, no. 2 (2010): 5-22.

xxviii Tonkin, Humphrey. “A Research Agenda for International Service Learning.” In International Service Learning: Conceptual Frameworks and Research, by Robert G. Bringle, Julie A. Hatcher, and Steven G. Jones, (Sterling, VA: Stylus, 2011), 191-224.

${ }^{\text {xxix }}$ Woolf, Michael, "Come and See the Poor People: The Pursuit of Exotica." Frontiers: The Interdisciplinary Journal of Study Abroad, 13, (2006): 135-146.

${ }^{\mathrm{xxx}}$ Handler, "Disciplinary Adaptation and Undergraduate Desire: Anthropology and Global Development Studies in the Liberal Arts Curriculum." 181-203.

${ }^{x x x i}$ Marullo, Sam, and Bob Edwards. "From Charity to Justice The Potential of University-Community Collaboration for Social Change." American Behavioral Scientist 43, no. 5 (2000): 895-912. 
${ }^{x x x i i}$ Butin, Dan W. Service-Learning in Theory and Practice: The Future of Community Engagement in Higher Education (New York: Palgrave Macmillan, 2010).

xxxiii Marullo, Sam, and Bob Edwards. "From Charity to Justice The Potential of University-Community Collaboration for Social Change.” American Behavioral Scientist 43, no. 5 (2000): 895-912.

xxxiv Intolubbe-Chmil et al. "Transformative learning: Participant perspectives on international experiential education." 165-180.

${ }^{\mathrm{xxxv}}$ Bain, Ken. What the Best College Teachers Do, (Cambridge, MA: Harvard University Press, 2004).

${ }^{x x x v i}$ The ESAVANA program is a network for transformative educational experiences involving engaged research, education and outreach between institutions of higher learning form the U.S. and eastern and southern Africa that has been in existence formally from 2002 until present.

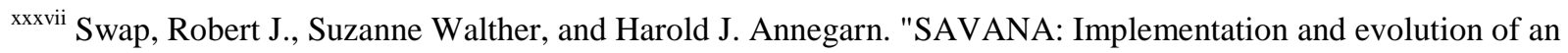
international research and education consortium." IIENetworker: The International Education, Fall 2008 (2008).

xxxviii Intolubbe-Chmil et al. "Transformative learning: Participant perspectives on international experiential education." 165-180.

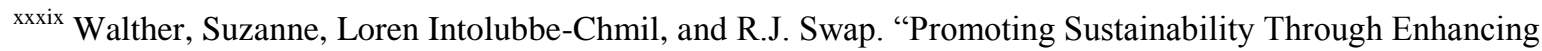
Resilience: Transdisciplinary Teaching and Learning in the Cross Cultural Context of ESAVANA.” In Teaching Sustainability: Perspectives from the Humanities and Social Sciences, edited by Wendy Petersen-Boring and William Forbes. Stephen F. Austin University Press, 2014.

${ }^{\mathrm{xl}}$ The UVA-Guatemala Initiative, formed at the encouragement and with the support of the Vice Provost for International Programs, has the role to facilitate the "development of sustainable and mutually beneficial relationships between UVA and the peoples and communities of Guatemala." Since that time, the UVA-GI has been continually mentored and guided by strong interdisciplinary leadership arising from the Schools of Medicine, Nursing, Engineering and Education.

${ }^{x l i}$ Feynman, Richard P. “What Is Science.” The Physics Teacher 7 (1969): 319. doi: 10.1119/1.2351388

${ }^{x l i i}$ A snow globe is a souvenir in which a miniature scene is sealed in a transparent globe. The globe contains a liquid and small plastic flakes of "snow." When the globe is shaken, the "snow" flakes circulate throughout the globe, falling on the scene.

${ }^{x}$ liii Costello, Amy, Rough Cut: South Africa: The Play Pump turning Water Into Child's Play, News Documentary, Frontline World, produced by Cassandra Herrman (Boston: WGBH, October 24, 2005), accessed December 13, 2013, http://www.pbs.org/frontlineworld/rough/2005/10/south_africa th.html.

${ }^{\text {xliv }}$ Costello, Amy, Troubled Water, News Documentary, Frontline World, (Boston: WGBH, June 29, 2010), accessed December 13, 2013, http://www.pbs.org/frontlineworld/stories/southernafrica904/video_index.html

${ }^{x l v}$ de Chastonay, Anne, Michael Bugas, Shreya Soni, and Robert Swap. "Community Driven Development of Rocket Stoves in Rural South Africa." International Journal for Service Learning in Engineering, Humanitarian Engineering and Social Entrepreneurship 7, no. 2 (2012): 49-68.

${ }^{x l v i}$ McDaniel, Maggie, Emerson Prebil, Robert Swap, Caroline Berinyuy, Dillon Chapman, Hallie Eilerts, and Jack McDaniel. "Community-Led Sanitation in Simoonga, Zambia." International Journal for Service Learning in Engineering, Humanitarian Engineering and Social Entrepreneurship 6, no. 2 (2011): 58-77. 
xlvii

Gregorian, "Colleges must reconstruct the unity of knowledge," B12.

xlviii These presentations have occurred at conferences and annual meetings of the following professional associations: the Association of American Geographers, the American Educational Research Association, the Atlantic Coast Conference International Academic Collaborative, the Forum on Education Abroad, the Gulf South Summit, and the International Association for Research on Service-Learning and Community Engagement.

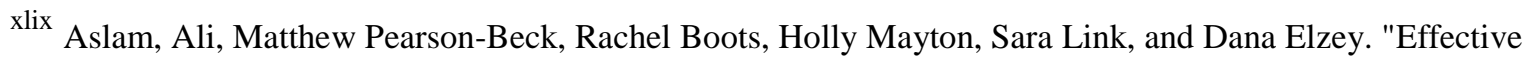
Community Listening: A Case Study on Photovoice in Rural Nicaragua." International Journal for Service Learning in Engineering, Humanitarian Engineering and Social Entrepreneurship 8, no. 1 (2013): 36-47.

${ }^{1}$ de Chastonay et al. "Community Driven Development of Rocket Stoves in Rural South Africa." 49-68.

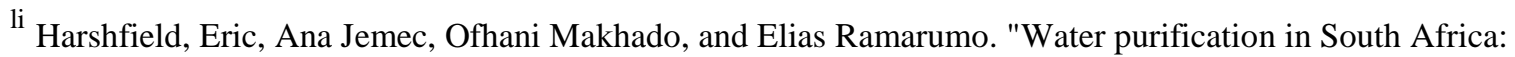
Reflections on curriculum development tools and best practices for implementing student-led sustainable development projects in rural communities." International Journal for Service Learning in Engineering, Humanitarian Engineering and Social Entrepreneurship 4, no. 1 (2009): 1-14.

${ }^{\text {lii } H e i l, ~ E t h a n, ~ D u n c a n ~ N e n g w e n a n i, ~ A u d r e y ~ R a e d a n i, ~ V e r o n i c a ~ G u t i e r r e z, ~ G a d i s i ~ N t h a m b e l e n i, ~ K h u t h a l a n i ~}$ Mathoma, Rachel Brown-Glazner, and Robert Swap. "Student-led, Community Driven Improvement of the Drinking Supply in a Rural Village in South Africa." International Journal for Service Learning in Engineering, Humanitarian Engineering and Social Entrepreneurship 5, no. 1 (2010): 94-110.

liii Intolubbe-Chmil et al. "Transformative learning: Participant perspectives on international experiential education." 165-180.

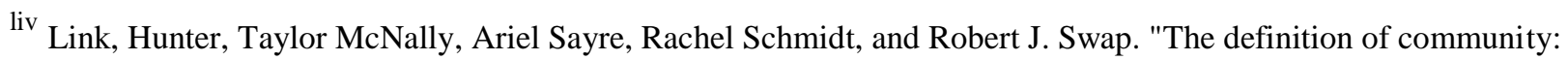
a student perspective." Partnerships: A Journal of Service-Learning and Civic Engagement (2012).

lv McDaniel et al. "Community-Led Sanitation in Simoonga, Zambia." 58-77.

${ }^{1 v i}$ Saboe, Daniel John, and Rodrigo Sarlo. "Finding Sustainable Solutions to the Digital Divide in Semi-Urban Honduras." International Journal for Service Learning in Engineering, Humanitarian Engineering and Social Entrepreneurship 5, no. 1 (2010): 170-188.

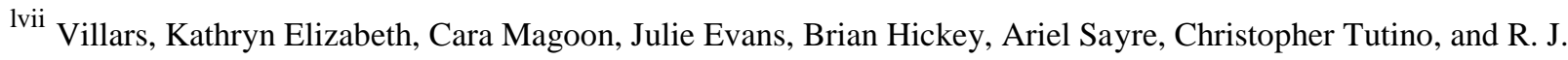
Swap. "Water Supply and Treatment Design in Rural Belize: A Participatory Approach to Engineering Action Research." International Journal for Service Learning in Engineering, Humanitarian Engineering and Social Entrepreneurship 5, no. 1 (2010): 47-63.

lviii Sockett, Hugh T. "Further Comment: Has Shulman Got the Strategy Right?." Harvard Educational Review 57, no. 2 (1987): 208-220.

lix Gregorian, "Colleges must reconstruct the unity of knowledge," B12.

1x Luscombe, Belinda. "10 Questions for Robert Reich.” Time, October 7, 2013. Retrieved from: http://content.time.com/time/magazine/article/0,9171,2153091,00.html October 4, 2013

${ }^{1 x i}$ Butin, Service-Learning in Theory and Practice: The Future of Community Engagement in Higher Education. 